\title{
Fertility of 'Morden Pink' Lythrum virgatum L. Transplanted into Wild Stands of $L$. salicaria $L$. in Manitoba
}

\author{
Cory J. Lindgren
}

Manitoba Purple Loosestrife Project, Oak Hammock Marsh, Box 1160

Stonewall, Manitoba ROC 2Z0, Canada

\author{
Robert T. Clay \\ Ducks Unlimited Canada, Oak Hammock Marsh, Box 1160 Stonewall, \\ Manitoba ROC 2Z0, Canada
}

Additional index words. hybridization, viable seeds, natural pollination, purple loosestrife

\begin{abstract}
Forty 'Morden Pink' Lythrum virgatum plants were transplanted into three wild stands of $L$. salicaria in June 1992. In Sept. 1992, seeds were collected and tested for viability and germination rates. Seed testing indicated that $83 \%$ of the collected seeds was viable (tetrazolium test) with a mean germination rate of $76 \%$. We conclude that 'Morden Pink' will cross-pollinate and produce viable seeds when exposed to wild $L$. salicaria stands.
\end{abstract}

Wild purple loosestrife (Lythrum salicaria) is an herbaceous European perennial that has become an invasive wetland species in North America since its introduction in the mid- 19th century. Its competitive ability and prolific seed production has resulted in its range's expanding across continental North America, thereby displacing much of the native wetland community in areas where it becomes established (Thompson, 1987).

Horticultural cultivars of purple loosestrife (Lythrum spp.) were developed in the mid1900s for use as garden and landscape ornamentals (Harp and Collicutt, 1967). These cultivars initially were thought to be sterile and, thus, safe for horticultural use. Recently, Ottenbreit (1991) reported that artificial crosses between 'Morden Pink', 'Morden Gleam' ( $L$. alatum Pursh $\times$ L. virgatum), 'Dropmore Purple' (L. salicaria $\times$ L. virgatum), and wild L. salicaria produced hybrid plants that were highly fertile. Further, Anderson and Ascher (1993) demonstrated that these cultivars are highly fertile when crossed with $L$. salicaria, L. alatum, or other cultivars. The authors of both of these papers concluded that purple loosestrife cultivars grown in gardens could serve as a pollen or seed source contributing to the spread of purple loosestrife in natural areas. Because both studies were conducted in

\footnotetext{
Received for publication 21 June 1993. Accepted forpublication July 1993. We thank Henry Murkin for reviewing earlier drafts; Lynn Collicutt (Agriculture Canada) for supplying plants for this study; Ducks Unlimited Canada for providing funding for purchasing plants and testing seeds; Dave Gray, Ron Lyseng, and Eric Claeys for the use of their land; Canada Trusts Friends of the Environment for funding; and members of the Manitoba Purple Loosestrife Project Committee. The cost of publishing this paper was defrayed in part by the payment of page charges. Under postal regulations, this paper therefore must be hereby marked advertisement solely to indicate this fact.
}

greenhouses using artificial pollination, additional field work was required to determine if cultivars actually cross-pollinate in the field by natural pollination.

The purpose of our study was to investigate whether 'Morden Pink' would produce viable seeds under natural conditions. We chose 'Morden Pink' for this study because it is a common garden cultivar and because it was least likely to produce viable seeds (Ottenbreit, 1991).

\section{Materials and Methods}

In June 1992,22 true stock 'Morden Pink' plants from the Agriculture Canada Field Station at Morden, Manitoba, and 18 'Morden Pink' plants purchased from garden centers in Winnipeg, Manitoba, were transplanted into three experimental sites: along the Red River north of Winnipeg (lat. $50^{\circ} 04^{\prime} \mathrm{N}$, long. $\left.96^{\circ} 55^{\prime} \mathrm{W}\right)$, along the La Salle River in Sanford (lat. $49^{\circ} 41^{\prime} \mathrm{N}$, long. $97^{\circ} 26^{\prime} \mathrm{W}$ ), and in a small wetland north of Cypress River (lat. $49^{\circ} 35^{\prime} \mathrm{N}$, long. $\left.99^{\circ} 04^{\prime} \mathrm{W}\right)$. Experimental plants were planted within or beside wild $L$. salicaria, except at the Red River site, where the nearest L. salicaria was $200 \mathrm{~m}$ upstream. Red flags were used to identify 'Morden Pink' transplants.

Seed capsules were collected from each transplant and wild $L$. salicaria plants in late Sept. 1992. Seed capsules then were assigned randomly to one of three seed-testing laboratories for germination and tetrazolium testing. Testing laboratories were Accu-Test Seed Laboratory (Rivers, Manitoba), Agriculture Canada (Saskatoon, Saskatchewan), and Newfield Seeds Co. (Nipawin, Saskatchewan). Tetrazolium testing consisted of presoaking the seeds in water for $24 \mathrm{~h}$, piercing them, then soaking them in a $0.2 \%$ tetrazolium solution for 12 to $48 \mathrm{~h}$. Germination testing was performed on seeds from the Cypress River site
Table 1. Viability of 'Morden Pink' Lythrum virgatum and $L$. salicaria seeds collected at three sites in Manitoba in 1992, as determined by tetrazolium testing.

\begin{tabular}{lcc}
\hline Site & $\begin{array}{c}\text { Plants } \\
\text { (no.) }\end{array}$ & $\begin{array}{c}\text { Viability }^{\mathbf{z}} \\
(\%)\end{array}$ \\
\hline Red River & & \\
$\quad$ Morden Pink & 12 & 93 \\
Cypress River & 10 & $81 \pm 3.0^{y}$ \\
$\quad$ Morden Pink & 2 & $95 \pm 1.4^{y}$ \\
$\begin{array}{l}\text { L. salicaria } \\
\text { La Salle River }\end{array}$ & & 77 \\
Morden Pink & 7 & 86 \\
L. salicaria & 2 &
\end{tabular}

${ }^{2}$ Each sample analyzed contained 200 seeds.

Mean of two samples.

only. Such testing consisted of seeds planted on top of blotters, moistened with water, and exposed to an alternating cycle of $16 \mathrm{~h}$ of darkness at $20 \mathrm{C}$ and $8 \mathrm{~h}$ of light at 30C; no chemicals were used. Chi-square analysis was used to analyze the data.

\section{Results and Discussion}

Of the original 40 'Morden Pink' transplants, 11 were destroyed before seed capsules were collected. For statistical purposes, where more than one test per lot was performed by a testing laboratory, the mean was used. Lythrum salicaria produced significantly more viable seeds per lot (one lot $=200$ seeds) when compared to 'Morden Pink' $\left(x^{2}=9.57, \mathrm{df}=1\right.$, $P \leq 0.002)$. Analysis revealed significant differences $\left(x^{2}=36.64\right.$, df $\left.=4, P \leq 0.001\right)$ between the number of viable seeds produced between sites; the reason for this difference is unknown. There were no significant differences $\left(x^{2}=3.38, \mathrm{df}=1, P>0.05\right)$ between the mean number of viable seeds produced by the 'Morden Pink' plants obtained from the Agriculture Canada Morden Field Station $(87 \%)$ and those purchased from local Winnipeg greenhouses (77\%). Further testing revealed a mean germination rate of $76 \%$ for 'Morden Pink' plants from the Cypress River site.

Our results indicate that 'Morden Pink' produced viable seeds within 4 months under natural conditions (Table 1). These results support Ottenbreit's (1991) and Anderson and Ascher's (1993) laboratory research indicating that purple loosestrife cultivars contribute viable seeds and pollen and, thus, contribute to the spread of purple loosestrife.

\section{Literature Cited}

Anderson, N.O. and P.D. Ascher. 1993. Male and female fertility of loosestrife (Lythrum) cultivars. J. Amer. Soc. Hort. Sci. (In press.)

Harp, H.F. and L. Collicutt. 1967. Lythrums for the home garden. Agriculture Canada, Ottawa.

Ottenbreit, K. 1991. The distribution, reproductive biology, and morphology of Lythrum species, hybrids and cultivars in Manitoba. MS Thesis, Univ. of Manitoba, Winnipeg.

Thompson. D.O., R.L. Stuckev. and E.B. Thompson. 1987. Spread, impact and control of purple loosestrife (Lythrum salicaria) in North American Wetlands. U.S. Dept. of the Interior, Fish and Wildlife Service, Washington, D.C. 